\title{
Characterization of mixed and monospecific stands of Scots pine and Maritime pine: soil profile, physiography, climate and vegetation cover data
}

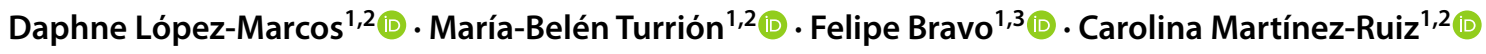

Received: 7 July 2020 / Accepted: 2 February 2021 / Published online: 22 March 2021

(c) The Author(s) 2021

\begin{abstract}
- Key message This document provides valuable environmental information about a triplets' essay of Scots pine and Maritime pine in Spain. The dataset characterizes the soil profile (physicochemical parameters of organic and mineral horizons), climate, physiography, understory and overstory. Dataset access is at https://doi.org/10.5281/zenodo. 4384530 and associated metadata is available at https://metadata-afs.nancy.inra.fr/geonetwork/srv/fre/catalog.search\#/ metadata/21cca830-daf9-4913-9b5b-a185d77943d5
\end{abstract}

Keywords Mixed stand $\cdot$ Pinus sylvestris $\cdot$ Pinus pinaster $\cdot$ Physicochemical soil profile parameters $\cdot$ Climatic parameters . Overstory features

\section{Background}

Many of the studies that highlight the role of mixed vs monospecific forests to supply ecosystem services are focused on mixtures that combine tree species with contrasting traits (Gamfeldt et al. 2013; Carnol et al. 2014; Almeida et al. 2018). However, little is known on the effect of mixing species that belong to the same genus (Forrester

\section{Handling Editor: Marianne Peiffer}

Contribution of the co-authors Daphne López-Marcos: designed the experiment, carried out the field and laboratory work, run the data analysis and wrote the paper.

María-Belén Turrión: designed the experiment, supervised the laboratory analyses and corrected the manuscript.

Felipe Bravo: designed the experiment, coordinated the research project and corrected the manuscript.

Carolina Martínez-Ruiz: designed the experiment, supervised the understory analyses and corrected the manuscript.

Daphne López-Marcos

dalomar86@hotmail.com

María-Belén Turrión

bturrion@agro.uva.es

Felipe Bravo

fbravo@pvs.uva.es

Carolina Martínez-Ruiz

caromar@agro.uva.es and Smith 2012; Mestre et al. 2017). Environmental parameters included here have contributed to increase knowledge on the functioning of six triplets of Scots pine (Pinus sylvestris L.) and Maritime pine (Pinus pinaster Ait.) in Spain. Soil characterization allowed to describe fertility and carbon dynamic along soil profile (López-Marcos et al. 2018), and the study of the understory and overstory features provided information about biodiversity functioning (LópezMarcos et al. 2020a) and its relationship with soil properties (López-Marcos et al. 2019).

The essay, located in North-Central Spain, consists of eighteen forest plots divided in six triplets. Each triplet includes three circular plots of 15-m radius located less than $1 \mathrm{~km}$ from each other: two monospecific plots dominated by $P$. sylvestris or $P$. pinaster, and one mixed plot of both species. In each plot, one pit up to $50 \mathrm{~cm}$ depth, one $15-\mathrm{m}$ radius overstory features inventory and ten understory

1 Sustainable Forest Management Research Institute UVaINIA, Avda. Madrid 50, 34071 Palencia, Spain

2 Dpto. de Ciencias Agroforestales, E.T.S. de Ingenierías Agrarias, Universidad de Valladolid, Campus La Yutera, Avda. Madrid 50, 34071 Palencia, Spain

3 Dpto. de Producción Vegetal y Recursos Forestales, E.T.S. de Ingenierías Agrarias, Universidad de Valladolid, Campus La Yutera, Avda. Madrid 50, 34071 Palencia, Spain 
$1 \times 1 \mathrm{~m}$ inventories were carried out. Additionally, physiographic and climatic variables were collected per plot.

\section{Methods}

\subsection{Study area}

The experimental area is located in North-Central Spain $\left(41^{\circ}\right.$ $47^{\prime} 35^{\prime \prime} \mathrm{N}$ and $41^{\circ} 53^{\prime} 41^{\prime \prime} \mathrm{N}$ latitude and $2^{\circ} 56^{\prime} 12^{\prime \prime} \mathrm{W}$ and $3^{\circ}$ $20^{\prime} 46^{\prime \prime} \mathrm{W}$ longitude; Table 1). It consists of eighteen forest plots distributed in six triplets located along an east-west axis of about $33 \mathrm{~km}$ and a north-south axis of about $11 \mathrm{~km}$ (Fig. 1). Each triplet comprises three circular plots of $15 \mathrm{~m}$ radius, including a plot dominated by $P$. sylvestris, another one by $P$. pinaster, and finally one mixed plot that contained both species. Plots within triplet are located less than $1 \mathrm{~km}$ from each other.

In this area, the forest management traditionally has consisted of strip clear-cutting with soil movement and planting or sowing when necessary and moderate thinning from below (Riofrío et al. 2019) benefiting P. sylvestris (López-Marcos et al. 2019). The stands have had no silvicultural intervention or damage in the last 10 years in an attempt to minimize the effect of the thinning or another type of intervention in what is intended to study either growth, floristic richness or soil nutrients. Triplets belong to the network of permanent plots of the Sustainable Forest Management Research Institute UVa-INIA (iuFOR). In this network, the mixture effect has been analysed on growth efficiency (Riofrío et al. 2017b; Cattaneo et al. 2020), crown morphology (Cattaneo et al. 2020), carbon stocks and exchangeable cations along the soil profile (López-Marcos et al. 2018), understory response to overstory (López-Marcos et al. 2019), understory richness and forest regeneration (López-Marcos et al. 2020a), height diameter and basal area increment (Riofrío et al. 2019) and changes in structural heterogeneity and stand productivity (Riofrío et al. 2017a).

\subsection{Sampling and data collection}

\subsubsection{Physiographic and climatic data collection}

The location, as Province, Municipality, Forest and geographical and UTM coordinates were obtained from ETRS 1989 UTM Zone 30N. The altitude was measured with GPS, the steepness with a clinometer and the orientation with a compass in the direction of maximum slope.

The Agroclimatic Atlas of Castilla y León (Nafría-García et al. 2013) was used to obtain precipitation and temperature data: rainfall and mean temperature in different months as well as accumulated rainfall and annual mean temperature for the period 1981-2010 (30 years; Nafría-García et al. 2013). The climate was classified according to the Köppen (1936) classification for the Iberian Peninsula.

Soil parent material and geological age were obtained from Spanish Geological Map (IGME 2015). The potential vegetation was derived from the Vegetation Series Map of

Table 1 Location and main characteristics of plots. ${ }^{\text {a} U n i t s: ~ m ~(U T M ~ P r o j e c t i o n ; ~ D a t u m ~ E T R S 89) ~}$

\begin{tabular}{|c|c|c|c|c|c|c|}
\hline Type of stand & Triplet & $\mathrm{XUTM}^{\mathrm{a}}$ & YUTM $^{\mathrm{a}}$ & Altitude (m) & Slope $(\%)$ & Orientation $\left({ }^{\circ}\right)$ \\
\hline \multirow[t]{6}{*}{ Pinus sylvestris monospecific stand } & 1 & 30T 471506 & 4638241 & 1146 & 6.60 & 48 \\
\hline & 2 & 30T 489013 & 4636689 & 1173 & 10.00 & 181 \\
\hline & 3 & 30T 498764 & 4636648 & 1277 & 15.60 & 202 \\
\hline & 4 & 30T 504084 & 4637638 & 1169 & 14.00 & 255 \\
\hline & 5 & 30T 503643 & 4631290 & 1145 & 0.01 & 250 \\
\hline & 6 & $30 \mathrm{~T} 504905$ & 4626883 & 1093 & 2.00 & 306 \\
\hline \multirow[t]{6}{*}{ Mixed stand } & 1 & 30T 471516 & 4638068 & 1154 & 6.20 & 23 \\
\hline & 2 & 30T 489048 & 4636639 & 1173 & 10.00 & 181 \\
\hline & 3 & 30T 498442 & 4636427 & 1241 & 18.70 & 200 \\
\hline & 4 & 30T 504572 & 4637209 & 1206 & 0.09 & 155 \\
\hline & 5 & 30T 503574 & 4631241 & 1159 & 0.04 & 100 \\
\hline & 6 & 30T 505080 & 4627036 & 1119 & 11.00 & 184 \\
\hline \multirow[t]{6}{*}{ Pinus pinaster monospecific stand } & 1 & 30T 471288 & 4638228 & 1154 & 6.20 & 23 \\
\hline & 2 & 30T 489066 & 4636618 & 1144 & 7.00 & 166 \\
\hline & 3 & 30T 498466 & 4636473 & 1277 & 19.00 & 200 \\
\hline & 4 & 30T 504454 & 4637173 & 1165 & 0.20 & 208 \\
\hline & 5 & 30T 503661 & 4631229 & 1145 & 0.01 & 250 \\
\hline & 6 & 30T 505265 & 4627124 & 1116 & 12.00 & 222 \\
\hline
\end{tabular}




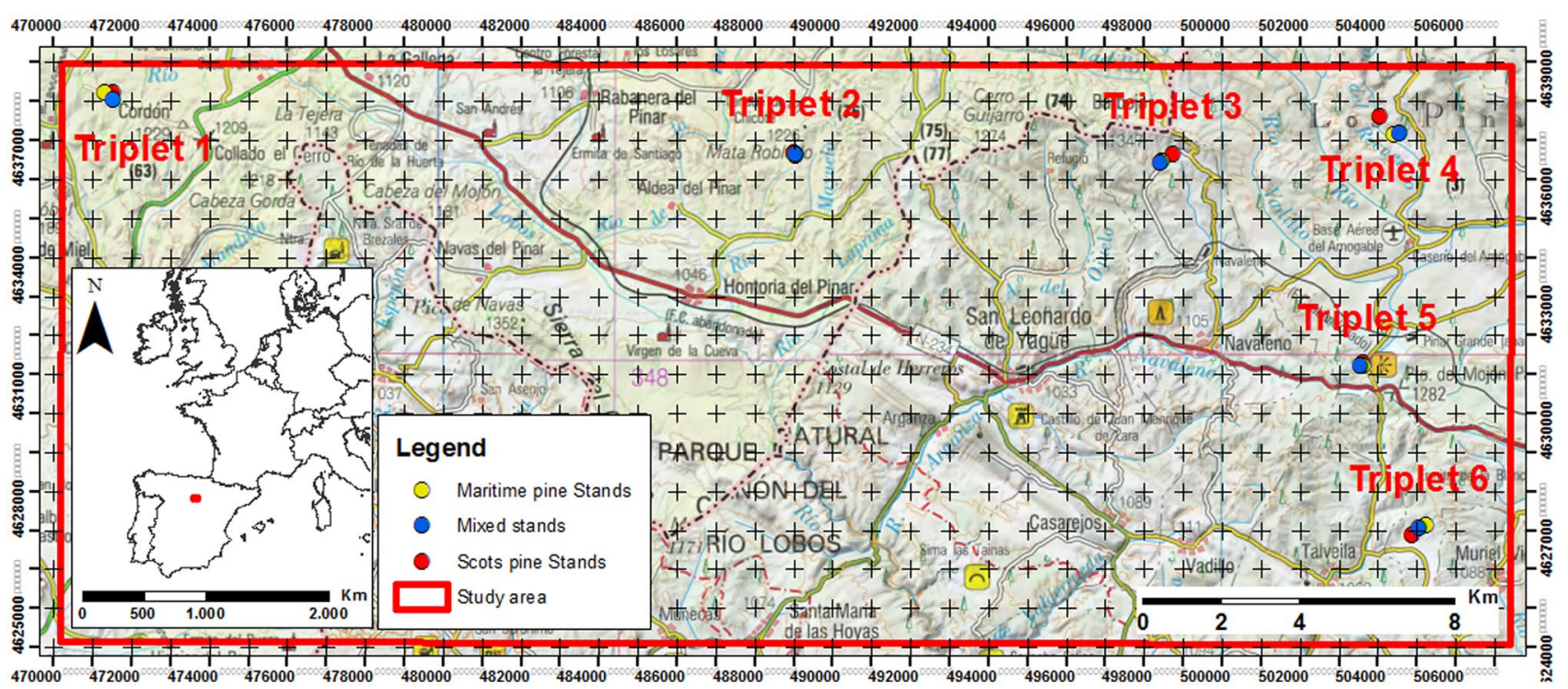

Fig. 1 Location of the triplets in the 'Sierra de la Demanda' in the North-Central Spain. Pinus sylvestris monospecific stands: red dots; Pinus pinaster monospecific stand: yellow dots; mixed stand of $P$. sylvestris and P. pinaster: blue dots

Spain (Rivas-Martínez 2011) and current vegetation from WMS service of MAPAMA.

\subsubsection{Soil sampling and analyses}

Soils were sampled in the spring of 2016. One soil pit of at least $50 \mathrm{~cm}$ depth was dug at each plot for organic and mineral soil horizon characterization. To collect, the forest was used a $25 \times 25 \mathrm{~cm}$ quadrant placed at the top of the pit. Coarse woody materials, such as large branches, were carefully removed from the forest floor before sampling (Andivia et al. 2016). The forest floor was separated into three fractions according to Van Delft et al. (2006): fresh, fragmented and humified fraction. The thickness of each horizon was measured, and one disturbed sample and two undisturbed soil samples were collected per horizon. The undisturbed soil samples were collected with steel cylinders keeping their original structure (López-Marcos et al. 2018, 2019). At the time of digging the soil pit, we estimated visually in each mineral horizon the moist and dry matrix colour for each horizon was determined with Munsell Charts (Munsell Color Company 2000; López-Marcos et al. 2018). Soil sampling and analyses were done as detailed in LópezMarcos et al. $(2018,2019)$.

Physical analyses included percentage by weight of coarse fraction ( $>2 \mathrm{~mm}$; stones), particle distribution determined by the pipette method (Van-Reeuwijk 2002) and subsequent determination of clay, sand and silt contents, and textural classification according to USDA criteria. Available water was determined as the difference between water content at field capacity and the permanent wilting point determined using a $\mathrm{pF}$ equipment (Bueis et al. 2016). Undisturbed mineral soil samples were weighed $( \pm 0.001 \mathrm{~g})$ and used to calculate the soil bulk density. The particle density was calculated with a pycnometer according to (Van-Reeuwijk 2002) and the porosity was calculated for each horizon using the bulk and particle densities.

Chemical parameters analysed for each mineral horizon included exchangeable cations $\left(\mathrm{Ca}^{+2}, \mathrm{Mg}^{+2}, \mathrm{~K}^{+}\right.$, $\mathrm{Na}^{+}$) extracted with $1 \mathrm{M}$ ammonium acetate at $\mathrm{pH}=7$ (Schollenberger and Simon 1945) and determined using an atomic absorption/emission spectrometer; cation exchange capacity according to Mehlich (1953); total organic carbon and total nitrogen quantified by dry combustion using a Leco CHN 2000 elemental analyser; easily oxidizable carbon analysed using the K-dichromate oxidation method (Walkley 1947); available phosphorus using the Olsen method (Olsen and Sommers 1982); and $\mathrm{pH}$ and electrical conductivity determined in a soil/water suspension in a ratio of 1:2.5 according to Van-Reeuwijk (2002).

In addition, the ratio of total organic carbon to total nitrogen of each horizon was calculated according to LópezMarcos et al. (2018), as well as the stocks of total organic carbon, easily oxidizable carbon, total nitrogen, available phosphorus, exchangeable sodium, potassium, calcium, magnesium and sum of bases according to López-Marcos et al. (2019). Water holding capacity per horizon and for the whole soil profile up to $50 \mathrm{~cm}$ depth was also calculated according to López-Marcos et al. (2019).

Once all the information per horizon was extracted, each horizon and soil type was named according to Soil-SurveyStaff (2014). 


\subsubsection{Overstory sampling}

The overstory was sampled in 2014-2015 (Riofrío et al. 2017a). In each plot, the number, diameter and height of all stems $>7.5 \mathrm{~cm} \mathrm{DBH}$ (diameter at the breast height) for every Pinus species were measured. The basal area was calculated as the sum of the sections at breast height and expressed per hectare. The age was determined from dendrochronological analysis of cores extracted with Pressler core-borer. The site index of both Pinus species was calculated with the dominant height of the plot and the related at age 100 for total plot; for Pinus sylvestris according to Rojo and Montero (1996) and for Pinus pinaster according to Bravo-Oviedo et al. (2007). In addition, the percentages of basal area of each Pinus species from total basal area were calculated.

\subsubsection{Understory sampling}

The sampling was carried out in June 2016 by the same observer to encompass and better identify the maximum number of vascular plant species (Martínez-Ruiz and Fernández-Santos 2005; Alday et al. 2010). In each plot, 10 quadrats of $1 \mathrm{~m} \times 1 \mathrm{~m}$ were randomly located to record the understory vegetation. In each quadrat, the cover percentages of leaf litter, vascular plant species (including tree regeneration) and of bryophytes were recorded.

The cover percentage of every vascular plant species in each quadrat was estimated visually "in situ" whenever possible. Specimens of the unknown or doubtful species were collected for later identification in the laboratory with the help of botanical keys such as Aizpiru et al. (2007) and Castroviejo et al. (1986-2012). Vascular plant species nomenclature follows Tutin et al. (1964-1980), and bryophytes nomenclature follows Crosby et al. (1992). Then, vascular plant species were classified by taxonomical groups (families) to estimate the cover percentage of each one. Also was calculated the most abundant specie of understory vegetation. All these variables are expressed as the average of ten quadrats per plot.

\section{Access to the data and metadata description}

The dataset (López-Marcos et al. 2020b) is available at Zenodo digital repository: https://doi.org/10.5281/zenodo. 4384530 and associated metadata is available at https:// metadata-afs.nancy.inra.fr/geonetwork/srv/fre/catalog. search\#/metadata/21cca830-daf9-4913-9b5b-a185d77943d5. The dataset covers a file whose filename is Dataset.csv. The file Dataset.csv contains information about the 218 environmental variables studied in the eighteen forest plots (18 columns). The first row (Plot) of the file Dataset.csv identifies the plot, the second row identifies the triplet to which it belongs (Triplet: 1-triplet 1; 2-triplet 2; 3-triplet 3; 4-triplet 4; 5-triplet 5; 6-triplet 6), and the third row identifies the stand type (Stand_type: PS-monospecific stand of Pinus sylvestris; MM-mixed stand; PP-monospecific stand of Pinus pinaster).

Plot characteristics include information about physiography, climate, soil profile, overstory and understory features. The physiographic data included the province (Province), the municipality (Municipality) and the name of the forest (Forest) where every plot is located, as well as the geographical coordinates (Lat and Long). Also included the altitude (Alti), the steepness (Slope), the orientation (Ori) and the potential (Pot_veg) and current (Cur_veg) vegetation of each plot.

The climate parameters include the climate Köppen classification (Clim), and the rainfall (R) and mean temperature (T) of different months (J: January; F: February; M: March; A: April; My: May; Jn: June; Jl: July; A: August; S: September; O: October; N: November; D: December). Also, the accumulated rainfall (XR) and the annual mean temperature (XT) are provided.

The soil data include some general information of the soil profile, as the soil parent material (Par_mat) and geological age (Geo_age) and the soil type (Soil).

The forest floor characterization was described by the forest floor thickness (FF_Th), the total leaf litter biomass (Litter_B) and the percentage of each litter fraction (freshFs; fragmented-Fg; humified-Hm). In addition, the total organic carbon (TOC), total nitrogen (TN) and the ratio of total organic carbon to total nitrogen $(\mathrm{C} / \mathrm{N})$ of each fraction were analysed.

The mineral characterization was carried out per horizon. In general, three mineral horizons were described up to $50 \mathrm{~cm}$ depth (first soil horizon: $\mathrm{H} 1$; second soil horizon: $\mathrm{H} 2$; third soil horizon: H3), so each variable analysed is tripled in the dataset. The variables analysed in each horizon were the thickness (Th); the moist (moistCol) and dry (dryCol) matrix colour; the coarse fraction (Stones); the clay (Clay), sand (Sand) and silt (Silt) contents; the textural classification (Tex); the field capacity (FC), the permanent wilting point (PWP) and the available water (AW); the soil bulk (bD) and particle (pD) density and porosity (Poro); the exchangeable sodium $\left(\mathrm{Na}^{+}\right)$, potassium $\left(\mathrm{K}^{+}\right)$, calcium $\left(\mathrm{Ca}^{+2}\right)$ and magnesium $\left(\mathrm{Mg}^{+2}\right)$, the sum of bases (SB) and the cation exchange capacity (CEC); the total organic carbon (TOC), total nitrogen (TN), easily oxidizable carbon $(\mathrm{OxC})$ and the ratio of total organic carbon to total nitrogen $(\mathrm{C} / \mathrm{N})$; the available phosphorus (avP), the $\mathrm{pH}$ and the electrical conductivity (EC). Also, the names of the genetic horizons $(\mathrm{G})$ were included following the Soil-Survey-Staff (2014) criteria. In addition, the stocks of some variables were calculated per horizon (first soil horizon: $\mathrm{H} 1$; second soil horizon: $\mathrm{H} 2$; third soil horizon: $\mathrm{H} 3$ ) and for the whole soil profile up to $50 \mathrm{~cm}$ depth (H50): total organic carbon stock (TOCstock), easily 
oxidizable carbon stock (OxCstock), total nitrogen stock (TNstock) available phosphorus stock (avPstock), exchangeable sodium stock $\left(\mathrm{Na}^{+}\right.$stock), exchangeable potassium stock $\left(\mathrm{K}^{+}\right.$stock), exchangeable calcium stock $\left(\mathrm{Ca}^{+2}\right.$ stock $)$, exchangeable magnesium stock $\left(\mathrm{Mg}^{+2}\right.$ stock), sum of bases stock (SBstock) and water holding capacity (WHC).

The overstory variables analysed in each plot are density $(\mathrm{N})$, basal area $(\mathrm{G})$, diameter $(\mathrm{dg})$ and height $(\mathrm{Ho})$ for every Pinus species (Pinus sylvestris-Ps and Pinus pinaster-Pp) and for the total plot $(\mathrm{T})$. In addition, this information includes the age (Age) and the site index (SI) of every Pinus species and the percentage of basal area of every Pinus species (\%PS-Pinus sylvestris; \%PP-Pinus pinaster).

The understory characterization includes the cover percentage of leaf litter (Litter_Cov), vascular plant species (Vasc) and bryophytes (Bryo). Also, it includes the cover percentage of each family (Aqu-Aquifoliaceae, Aste-Asteraceae, Cari-Caryophyllaceae, Cist-Cistaceae, Cupr-Cupressaceae, Eric-Ericaceae, Faba-Fabaceae, FagaFagaceae, Junc-Juncaceae, Lili-Liliaceae, Pina- Pinaceae, Poac-Poaceae, Poli- Polygalaceae, Rosa-Rosaceae, RubiRubiaceae, Scro- Scrophulariaceae, Viol-Violaceae, XantXanthorrhoeaceae), and of the most abundant specie of the understory (Under_sp).

\section{Technical validation}

The validation of the dataset was carried out through a first by hand verification and complemented by numerical and graphical analyses. Laboratory equipment was regularly calibrated, and standards were used on each analysis. Soil analyses were conducted in duplicate and mean values are presented. Understory analyses were conducted in ten quadrats per plot and the average values are presented. Every record was revised in relation to the normal range of values for each variable. Related variables were examined and tested for inconsistencies basing on their correlations and corrected when necessary.

\section{Reuse potential and limits}

The original dataset brings valuable information about a triplets' essay of Scots pine and Maritime pine in NorthCentral Spain. The dataset addresses the physicochemical characterization of the organic and mineral horizons of the soil profile, physiography, climate, understory and overstory features.

The reuse of the data presented here is simple. This is a.csv file ready to be loaded into Software as R. For more information, users can refer to the metadata description files.

Part of these data has already been used successfully in previous studies. First of all, when the carbon storage and exchangeable cations along the soil profile were studied, two trends were found: in the topsoil, higher values of carbon stock and total organic carbon were found in $P$. sylvestris stands, lower in P. pinaster stands and intermediate in mixed stands; this pattern was related to the $\mathrm{C} / \mathrm{N}$ ratio of the forest floor. In the intermediate soil layers, carbon stock and total organic carbon tended to be higher in mixed stands and it was related to the higher percentage of fine roots and greater thickness of the first mineral horizon. Differences in soil exchangeable cations among stands were related to the total organic carbon content (López-Marcos et al. 2018). When the understory composition and its relationship with the soil status were assessed, a water-stress gradient associated with the overstory composition indicated that $P$. pinaster tolerates lower soil water content than $P$. sylvestris. Mixed stands were under greater water stress conditions than $P$. sylvestris monospecific stands but maintained the same level of understory richness. In addition, a soil fertility gradient defined by organic carbon and exchangeable-magnesium stocks was identified (LópezMarcos et al. 2019). Finally, when understory species composition was analysed, the percentage of the basal area of both Pinus species was found to be the only characteristic of the stand that significantly influenced the understory composition. Species characteristics of humid and temperate zones, including $P$. sylvestris regeneration, dominated in $P$. sylvestris monospecific stands. Typical species of well-drained Mediterranean areas, including $P$. pinaster regeneration, dominated in $P$. pinaster monospecific stands. In mixed stands, the highest regeneration of the native Pyrenean oak (Quercus pyrenaica Willd.) was accompanied by typical species that share the same regeneration niche (López-Marcos et al. 2020a).

Acknowledgements We would like to thank Luis Alfonso Ramos Calvo for his invaluable help with soil sampling, Carmen Blanco and Juan Carlos Arranz for their advice in the laboratory analyses, José Riofrío and Cristóbal Ordóñez for their assistance in the characterization and location of plots in the field and the Regional Forest Service of Castilla and León to facilitate the triplets installation and monitoring.

Funding This research was funded by a predoctoral grant to DLM (BES-2015-072852) and the Project FORMIXING (AGL201451964-C2-1-R) from the Ministry of Economy and Competitiveness of the Spanish Government and Competitiveness of the Spanish Government and a subsidy for the acquisition of scientific equipment (LECO equipment) within the framework of the network of scientifictechnological equipment in Castilla y León "infrared" co-financed by the European Regional Development Fund.

Data availability The datasets generated during the current study are available in the ZENODO repository https://doi.org/10.5281/zenodo. 4384530 . 


\section{Declarations}

Conflict of interest The authors declare that they have no conflict of interest.

Open Access This article is licensed under a Creative Commons Attribution 4.0 International License, which permits use, sharing, adaptation, distribution and reproduction in any medium or format, as long as you give appropriate credit to the original author(s) and the source, provide a link to the Creative Commons licence, and indicate if changes were made. The images or other third party material in this article are included in the article's Creative Commons licence, unless indicated otherwise in a credit line to the material. If material is not included in the article's Creative Commons licence and your intended use is not permitted by statutory regulation or exceeds the permitted use, you will need to obtain permission directly from the copyright holder. To view a copy of this licence, visit http://creativecommons. org/licenses/by/4.0/.

\section{References}

Aizpiru I, Aseginolaza C, Uribe-Echebarría PM et al (2007) Claves ilustradas de la Flora del País Vasco y Territorios Limítrofes, 2a. Gobiertno Vasco. Departamento de Medio Ambiente y de Oedenación del Territorio, Vitoria (Spain)

Almeida I, Rösch C, Saha S (2018) Comparison of ecosystem services from mixed and monospecific forests in Southwest Germany: A survey on public perception. Forests 9:628. https://doi. org/10.3390/f9100627

Alday JG, Martínez-Ruiz C, Marrs RH, Bravo F (2010) Influence of harvesting intensity on the floristic composition of natural Mediterranean maritime pine forest. Acta Oecol 36:349-356. https://doi.org/10.1016/j.actao.2010.03.001

Andivia E, Rolo V, Jonard M et al (2016) Tree species identity mediates mechanisms of top soil carbon sequestration in a Norway spruce and European beech mixed forest. An For Sci 73:437447. https://doi.org/10.1007/s13595-015-0536-z

Assmann E (1970) The principles of forest yield study. Studies in the organic production, structure, increment and yield of forest stands. Oxford, UK

Bravo-Oviedo A, del Río M, Montero G (2007) Geographic variation and parameter assessment in generalized algebraic difference site index modelling. For Ecol Manage 247:107-119. https:// doi.org/10.1016/j.foreco.2007.04.034

Bueis T, Bravo F, Pando V, Turrión MB (2016) Relationship between environmental parameters and Pinus sylvestris L. site index in forest plantations in northern Spain acidic plateau. iForest 9:394-401. https://doi.org/10.3832/ifor1600-008

Castroviejo S, Lainz M, López G, et al (1986-2012) Flora Ibérica. Real Jardin Botánico de Madriod - CSIC, Madrid (Spain)

Crosby M, Magill R, Bauer C (1992) Index of Mosses, 1963-1989. Monographs in Systemmatic Botany from Missouri Botanical Grden

Carnol M, Baeten L, Branquart E et al (2014) Ecosystem services of mixed species forest stands and monocultures: comparing practitioners and scientists perceptions with formal scientific knowledge. Forestry 87:639-653. https://doi.org/10.1093/forestry/cpu024

Cattaneo N (2018) Competencia, prductividad y cambios a nivel de copas en bosques mixtos de pinos mediterráneos. Señales a nivel de árbol individual. PhD Thesis. University of Valladolid

Cattaneo N, Schneider R, Bravo F, Bravo-oviedo A (2020) Interspecific competition of tree congeners induces changes in crown architecture in Mediterranean pine mixtures. For Ecol Manage 476:118471. https://doi.org/10.1016/j.foreco.2020.118471

Forrester DI, Smith RGB (2012) Faster growth of Eucalyptus grandis and Eucalyptus pilularis in mixed-species stands than monocultures. For Ecol Manage 286:81-86. https://doi.org/10.1016/j. foreco.2012.08.037

Gamfeldt L, Snäll T, Bagchi R et al (2013) Higher levels of multiple ecosystem services are found in forests with more tree species. Nat Commun 4:1340. https://doi.org/10.1038/ncomms2328

IGME (2015) Mapa Geológico de la Península Ibérica, Baleares y Canarias a escala $1 \mathrm{M}$.

Köppen W (1936) Das geographische System der Klimate. In: Handbuch der Klimatologie. pp 7-30

López-Marcos D, Martínez-Ruiz C, Turrión MB et al (2018) Soil carbon stocks and exchangeable cations in monospecific and mixed pine forests. Eur J For Res 137:831-847. https://doi. org/10.1007/s10342-018-1143-y

López-Marcos D, Turrión M, Bravo F, Martínez-Ruiz C (2019) Understory response to overstory and soil gradients in mixed versus monospecific Mediterranean pine forests. Eur J For Res 138:939-955. https://doi.org/10.1007/s10342-019-01215-0

López-Marcos D, Turrión M, Bravo F, Martínez-Ruiz C (2020a) Can mixed pine forests conserve understory richness by improving the establishment of understory species typical of native oak forests? Ann For Sci 77:15

López-Marcos D, Martínez-Ruiz C, Turrión M, Bravo F (2020b) Soil profile, climatic, physiographic, overstory and understory data in mixed and monospecific plots of Pinus sylvestris and Pinus pinaster in Spain. (Version V 2.0). Zenodo. https://doi. org/10.5281/zenodo.4384530

Martínez-Ruiz C, Fernández-Santos B (2005) Natural revegetation on topsoiled mining-spoils according to the exposure. Acta Oecol 28:231-238. https://doi.org/10.1016/j.actao.2005.05.001

Mehlich A (1953) Rapid determination of cation and anion exchange properties and pH of soils. J Assoc Off Agric Chem 36:445-457

Mestre L, Toro-Manríquez M, Soler R et al (2017) The influence of canopy-layer composition on understory plant diversity in southern temperate forests. For Ecosyst 4:6. https://doi. org/10.1186/s40663-017-0093-z

Munsell Color Company (2000) Munsell Soil Color Charts. Munsell Color Co., Balltimore MD

Nafría-García DA, Garrido-del-Pozo N, Álvarez-Arias MV et al (2013) Atlas agroclimático de Castilla y León, 1st edn. Instituto Tecnológico Agrario, Junta de Castilla y León- Agencia Estatal de Meteorología

Olsen SR, Sommers LE (1982) Phosphorus. In: Page AL, Miller RH, Keeney DR (eds) Methods of Soil Analysis. American Society of Agronomy, Madison, WI (USA), pp 403-427

Riofrío J, del Río M, Maguire D, Bravo F (2019) Species mixing effects on height-diameter and basal area increment models for Scots pine and Maritime pine. Forests 10:249. https://doi. org/10.3390/f10030249

Riofrío J, del Río M, Pretzsch H, Bravo F (2017) Changes in structural heterogeneity and stand productivity by mixing Scots pine and Maritime pine. For Ecol Manage 405:219-228. https://doi. org/10.1016/j.foreco.2017.09.036

Riofrío J, del Río Bravo MF (2017) Mixing effects on growth efficiency in mixed pine forests. Forestry 90:381-392. https://doi. org/10.1093/forestry/cpw056

Rivas-Martínez S (2011) Mapa de series, geoseries y geopermaseries de vegetación de España - Parte II. Itinera Geobot 18:5-424

Rivas-Martínez S (1987) Memoria del mapa de series de vegetación de España. Serie Técnica, Madrid (Spain)

Rojo A, Montero G (1996) El pino silvestre en la Sierra de Guardarrama. Ministerio de Agricultura, Pesca y Alimentación, Madrid (Spain) 
Schollenberger CJ, Simon RH (1945) Determination of exchange capacity and exchangeable bases in soil - ammonium acetate method. Soil Sci 9:13-24

Soil-Survey Staff (2014) Keys to Soil Taxonomy, 12th edn. USDANatural Resources Conservation Service, Washington, DC (USA)

Tutin TG, Heywood VH, Burges NA et al (1964-1980) Flora Europaea. Cambridge University Press, Cambridge (UK)

Van Reeuwijk L (2002) Procedures for Soil Analysis, 6th edn. ISRIC, FAO, FAO
Van Delft B, de Waal RW, Kemmers RH et al (2006) Field guide for the description and classification of humus forms. Wageningen University, Wageningen (Nederland), Alterra

Walkley A (1947) A critical examination of rapid method for determining organic carbon in soils. Soil Sci 63:251-254. https://doi. org/10.1097/00010694-194704000-00001 